\title{
Narrative Construction, Ideal Rule, and Emotional Discourse in the Biographies of Șalāḥ al-Dīn and Louis IX by Bahā' al-Dīn b. Shaddād and Jean Sire de Joinville ${ }^{1}$
}

\author{
Gowaart Van Den Bossche
}

\begin{abstract}
Bahā' al-Dīn b. Shaddād and Jean Sire de Joinville wrote two unrelated but remarkably similar biographies of the rulers they once served, Șalāh al-Dīn and Louis IX. Especially striking are two anecdotes in which both Ibn Shaddād and Joinville rebuke the ruler for excessive crying upon receiving the news of a close relative's death. This essay explores the narrative logic that drove these authors to write their texts and these anecdotes in particular in such a similar way. By embedding their discourse on emotional restraint in the wider discursive matrix of advice literature circulating in the period, Ibn Shaddād and Joinville actively participated in narrative discussions on ideal rule. In this they did not only stress the importance of emotional restraint for a ruler, but also the necessity of employing good advisors, ideally exemplified by themselves.
\end{abstract}

Keywords: narrative construction; ideal rule; Bahā’ al-Dīn b. Shaddād; Jean Sire de Joinville; Louis IX; Ṣalāḥ al-Dīn

Bahā' al-Dīn b. Shaddād (d. 632 AH / 1234 CE) ${ }^{2}$ and Jean Sire de Joinville (d. 1317) lived almost a century apart at opposite ends of the Mediterranean. Yet, when reading

\footnotetext{
${ }^{1}$ The version of Record of this manuscript has been published and is available in al-Masaq 2018, https://www.tandfonline.com/doi/full/10.1080/09503110.2018.1475973 Earlier drafts of this essay were presented at the British Association for Islamic Studies conference in London in 2016, and at the "Emotions, Imaginations, and Communities in the Medieval Mediterranean Society" conference organised by the Society for the Medieval Mediterranean in Ghent in 2017. I am grateful to Jo Van Steenbergen, Jan Dumolyn, Konrad Hirschler, Maya Termonia, Kristof D'hulster and the anonymous reviewers of alMasaq for their many helpful comments on earlier drafts.
} 
their respective regnal biographies of the sultan of Egypt and Greater Syria al-Malik alNāṣir Șalāḥ al-Dīn Yūsuf b. Ayyūb (d. 1193) — known as Saladin in the European tradition — and the French king Louis IX (d. 1270), one is struck by a number of remarkable similarities. In general, it can be observed that the authors are very present in their narratives as intimate companions of the rulers during crucial phases of their reigns. For both writers, these periods of sustained close interaction with the sovereign were in fact relatively short — the last six years of Șalāh al-Dīn's life and the six years Louis IX spent on the Seventh Crusade, respectively -- but heavily dominate the biographies' contents: narratives directly related to these periods constitute up to three quarters of the whole. ${ }^{3}$ Furthermore, both texts extensively discuss the ruler's virtues in preliminary sections and in the biographical narratives, but they also contain a number of more critical anecdotes. Perhaps the most striking convergence is one anecdote in each of the texts in which the ruler is depicted as displaying excessive grief for the death of a close relative — Șalāḥ al-Dīn's nephew and Louis' mother, respectively — upon which the author-companion urges him to govern his emotions in a way appropriate for a monarch.

Why did two authors so far removed in time and place construct such similar narratives? It is of course entirely possible that these accounts are more or less accurate representations of the real-life grief of the rulers for an intimate relative and that the

\footnotetext{
${ }^{2}$ Dates will only be given in common era in the remainder of this essay.

${ }^{3}$ Michèle Perret noted that Joinville himself has a role in $73 \%$ of the 768 paragraphs in which his text was divided by its editors. M. Perret, “...A la fin de sa vie ne fuz-je mie”, Revue des sciences humaines, 183 (1981-3): 18. In D.S. Richards' translation of Ibn Shaddād's text, the chronological narrative starts on page 41 , our author first appears on page 80 , and the text continues detailing the remaining six years of the sultan's life until page 245. Bahā’ al-Dīn b. Shaddād, The Rare and Excellent History of Saladin, trans. D.S. Richards (Farnham/Burlington: Ashgate, 2002).
} 
likeness between the reaction of their companions is mere coincidence. However, other structural and specific similarities throughout the texts suggest that there may be more to this anecdote on a narrative level. This essay will study these anecdotes and the texts in which they appear as comparable constructions in which authors from very different backgrounds engaged with ideas about ideal rule that were to some degree shared between their respective worlds. As such, I will explore parallel authorial practices of narrating the specific life of a ruler and the concomitant narrative construction of an example of ideal rule, with a specific focus on their respective emotional discourses in these particular anecdotes. Moving on from the hypothesis that Ibn Shaddād's and Joinville's shared framework of reference must have been at least partially informed by the tradition of advice literature that was widespread both in Europe and the Islamic world, I will investigate how the authorial practices of narrating the historical specifics of one ruler's actions, reproducing conceptions of ideal rule, and presenting the sovereign's relations with intimate companions intersected in ways both unique and remarkably convergent. The authors themselves will be shown to be the crucial nodes here, as it is through their narrative presence as what I call author-companions that these various goals are mediated. Both authors could claim to have personally attended to the ruler during crucial phases of their reign and subsequently argued for the superiority of their accounts of these periods. By linking the emotional discourse of these anecdotes to excerpts from selected advice texts, it will become clear that both Ibn Shaddād and Joinville embedded their narrative of the ruler's emotional composure in discourses on necessary restraint on the one hand, and on the necessity of employing able advisors on the other hand.

Although the history of emotions has been a fruitful field of research in recent years, this essay aims to participate only in its debates insofar as they are related to the 
specific textual application of emotion. ${ }^{4}$ I will be taking emotional discourse as one possible gateway into exploring the narrative construction of texts and the authorial agency involved, highlighting the ways in which authors made use of received ideas on the restraint of emotions, and the importance of advice in a broader framework of ideal rule to construct convincing narratives of one ruler's life. While the first two parts of this essay will discuss the texts and the particular anecdotes, the third part will be concerned with traces of similar ideas in advice literature that circulated in the direct environments of our authors. In concluding I will then discuss how these currents of emotional discourse interacted within the textual frameworks of the biographies. It will be suggested that the personalities of our authors as embedded in the texts can be seen as a literary vector not only for the portrayal of ideal emotional governance, but also of an idealised, mutually reinforcing relationship between a ruler and his advisors.

\section{Situating the authors and the regnal biographies}

As defined by Chase Robinson, in the Islamic historiographical tradition biographies are "single-subject works that relate the life of a person, the coverage usually being representative rather than comprehensive." He furthermore talks of "the paradigmatic force of biographical writing," highlighting the ways in which authors used the life of a

\footnotetext{
${ }^{4}$ For an overview of the various ways in which medievalists have looked at textual representations of emotions, see: B. Rosenwein, "Thinking Historically about Medieval Emotions", History Compass, 8, vol. 8 (2010): 828-842. My approach to emotional discourse is closest to Rosenwein's own paradigm of treating emotions as pertaining to "a norm within an emotional community." (p. 828, 831-833) See also her important study Emotional Communities in the Early Middle Ages (Ithaca/London: Cornell University Press, 2006).
} 
person as a way to exemplify their personal views on political and religious matters. ${ }^{5}$ As we shall see, this is also very much true of Joinville's biographical project, in which he explicitly uses the life and actions of Saint Louis to exemplify an ideal type of a ruler as well as a saint. Both Ibn Shaddād and Joinville conceived of their regnal biographies as works that portrayed a "paradigmatic" picture of ideal rule.

However, although they are as a result today primarily seen as biographerhistorians, both our authors in fact only wrote one text that unambiguously fits the mould of historical biography. Ibn Shaddād was a prominent member of the learned social group of the 'ulamā', with a specialisation in hadīth and fiqh. This is evident from the fact that he served Ṣalāḥ al-Dīn in the first place as his qậ̣̂ al- 'askar or army judge, and that most of his works can be situated in the domains of traditionalism and law. ${ }^{6}$ Joinville on the other hand was a nobleman (seneschal) from the Champagne who wrote a few other works, but none of these known or supposed other writings come anywhere near the length and breadth of issues dealt with in the Vie de Saint Louis, and neither are they historical-biographical. ${ }^{7}$

Ibn Shaddād entitled his work al-Nawādir al-sulțaniyya wa-l-mahāsin alYūsufiyya ("The sultanic rarities and the merits of Yūsuf"), ${ }^{8}$ but the two earliest manuscripts also (or only) bear the more concise title Kitāb sīrat al-Malik al-Nāṣir

${ }^{5}$ C.F. Robinson, Islamic Historiography (Cambridge: Cambridge University Press, 2003), xxiv.

${ }^{6}$ The Rare and Excellent History, 3-4.

${ }^{7}$ Jean Sire de Joinville, Vie de Saint Louis, ed. J. Monfrin (Paris: Garnier, 1995), 27-32;

Joinville and Villehardouin: Chronicles of the Crusades, trans. C. Smith (London: Penguin, 2008), xxxvi.

${ }^{8}$ Bahā' al-Dīn b. Shaddād, Al-Nawādir al-sulțāniyyah wa-l-maḥāsin al-Yūsufiyyah, aw Sìrat Șalāh al-Dīn, ed. Jamāl al-Dīn al-Shayyāl (Cairo: Maktabat al-Khānjī, second edition, 1994). 
Șalāh al-Dīn Yūsuf b. Ayyūb ("The book of the biography of al-Malik al-Nāṣir Șalāḥ alDīn Yūsuf b. Ayyūb”) on their title pages. ${ }^{9}$ Although the author does not explicate the meaning of his first title, the referral to Yūsuf probably denotes both Șalāḥ al-Dīn's personal name and the Qur'ānic prophet of the same name, who was considered to be "a model of virtue and wisdom." ${ }^{, 10}$ Further on in the text, Ibn Shaddād notes a similarity between an anecdote about the sultan and a story about this prophet, and he uses a quote from the Qur'ān about Yūsuf to describe an action of Șalāḥ al-Dīn. ${ }^{11}$

The closest contemporary relatives to al-Nawädir al-sultaniyya are two heavily memoiristic histories written by Ibn Shaddād's close colleague 'Imād al-Dīn al-Kātib alIșfahānī (d. 1201), al-Fath al-Qussī fì l-fath al-Qudsī ("Qussian Eloquence on the Conquest of Jerusalem") and al-Barq al-Shāmī ("The Syrian Lightning”). ${ }^{12}$ Indeed, Ibn Shaddād relied extensively on them for the earlier years of Șalāh al-Dīn's life and sultanate. ${ }^{13}$ However, the writing style of these works is much more ornate and stylistically dense with allusions and metaphors. This verbose literary style called insh $\bar{a}$, had become highly popular in Persian historiography and al-Iṣfahānī, who was a native

\footnotetext{
${ }^{9}$ Bahā' al-Dīn b. Shaddād, Al-Nawādir al-sulțānīyah wa-l-mahāasin al-Yūsufìyah,
}

Staatsbibliothek zu Berlin, Wetzstein II 1893, folio 1r.; Islamic Museum, al-Aqșā Mosque / al-Haram al-Shariff, 203, folio 1r. The title is not present on the Berlin manuscript's title page, but it is mentioned in its introduction, Wetzstein II 1893, folio $2 \mathrm{v}$.

${ }^{10}$ R. Firestone, "Yūsuf", Encyclopedia of Islam, Second Edition, in:

http://referenceworks.brillonline.com/entries/encyclopaedia-of-islam-2/yusuf-

COM 1369?s.num=0\&s.f.s2 parent=s.f.book.encyclopaedia-of-islam-2\&s.q=yusuf

${ }^{11}$ Al-Nawādir, 85 and 210; The Rare and Excellent History, 47 and 126.

12 'Imād al-Dīn al-Kātib al-Iṣfahān̄i, Kitāb al-fatḥ al-Qussī fì l-fatḥ al-Qudsī (Leiden: Brill, 1888). Only two parts of the original seven-volume al-Barq al-Shāmī survive, vol. 3 ed. Mustafā al-Hayarī, vol. 5 ed. Fālih Ḥussayn (Amman: Mu’assasat 'Abd al-Hamid Shuman, 1987). Al-Fath was admirably but incompletely translated into French by Henri Massé in: Conquête de la Syrie et de la Palestine par Saladin (Paris: Geuthner, 1972).

${ }^{13}$ The Rare and Excellent History, 5. 
speaker of Persian, may be considered as one of its most important advocates in the Arabic historiographical tradition. ${ }^{14}$ Although parts of Ibn Shaddād's text were also written in rhymed prose, Ibn Shaddād's style is in general much more straightforward and less stylistically inclined than al-Ișfahānī’s. Furthermore, Ibn Shaddād's personal "presence" in the text is used in noticeably different ways: less as a boastful central node than as a lens through which the text is meant to gain a higher degree of verisimilitude, as I will argue below.

D.S. Richards has claimed that al-Nawädir must have been intended to circulate in Ayyūbid courtly circles of the early thirteenth century as a hybrid of historical narrative and advice literature. ${ }^{15}$ He also plausibly assumed that Ibn Shaddād finished his text in old age, decades after the sultan's death, most probably while serving his son al-Ẓāhir Ghāzī (d. 1216), considering the fact that several favourable comments about the latter can be found throughout the narrative. ${ }^{16}$ Further research on the dozen or so extant manuscripts of the text would be necessary to establish these claims with more

${ }^{14}$ L. Richter-Bernburg, “'Imād al-Dīn al-Iṣfahānī”, Medieval Muslim Historians and the Franks in the Levant, ed. A. Mallett (Leiden/Boston: Brill, 2014), 74-75 and passim. On the "ornate style" of Persian historiography, see: J.S.Meisami, "History as Literature", Iranian Studies, 33 vol. 1/2 (2000): 15-30. The most famous example of the style's use in Arabic historiography before al-Iṣfahānī is al- 'Utbī's (d. 1040) al-Kitāb al-Yaminnī. On this work and on some ways in which it influenced Arabic historical writing (though never as profoundly as in Persian): Robinson, Islamic Historiography, 98-99.

${ }^{15}$ D.S. Richards, "A Consideration of Two Sources for the Life of Saladin" Journal of Semitic Studies, 25, vol. 1 (1980): 53-54. Stefan Leder more generally argued that the text can "be read as a manual of good governance" in addition to its historiographical content, "Sunni Resurgence, Jihad Discourse and the Impact of the Frankish Presence in the Near East", in Crossroads between Latin Europe and the Near East: Corollaries of the Frankish Presence in the Eastern Mediterranean 12th-14th Centuries, ed. S. Leder (Würzburg: Ergon Verlag, 2011), 94.

${ }^{16}$ The Rare and Excellent History, 5-7. 
certainty. The Berlin manuscript of al-Nawädir does indeed suggest something along these lines: it contains at least two notes that refer to non-ruling members of the Ayyubid clan. Furthermore, other notes on the manuscript refer directly to Balabān alRūmī (d. 1281), dawādār (bearer of the inkwell) of the early Mamluk sultan al-Zāhir Baybars (r. 1260-1277), and to the viceroy of Qalāwūn (r. 1298-1290), Ḥusām al-Dīn Țurunțāy (d. 1290). This shows its enduring circulation in courtly circles at least during the century following its first dissemination. ${ }^{17}$ P.M. Holt has also argued that Ibn Shaddād’s tripartite structure influenced Muḥȳ̄ al-Dīn Ibn 'Abd al-Ẓāhir's (d. 1293) regnal biography of Baybars, al-Rawd al-zāhir fì sīrat al-Malik al-Ẓāhir. ${ }^{18}$ Here too, a first short section about the sultan's early life is followed by a discussion of the ruler's virtues and then a long account of his reign. The fact that Ibn 'Abd al-Zāhir, as leader of Baybars' chancery (șạhị dīwān al-inshā') worked closely with Balabān al-Rūmī, and probably also with the powerful Țurunțāy, may indeed argue for the influence of Ibn Shaddād's biography on early Mamluk period conceptions of ideal rule. ${ }^{19}$

The oldest manuscript of Joinville's vernacular Old French biography bears no explicit title and is commonly referred to simply as Vie de Saint Louis, although Joinville does refer to the book as "un livre des saintes paroles et des bons faiz nostre saints roy Looÿs" in his introduction. ${ }^{20}$ It was not a very popular text judging by its survival in manuscript form: three manuscripts are extant, only one of which is near-

${ }^{17}$ Bahā' al-Dīn b. Shaddād, Al-Nawādir al-sulțānīyah wa-l-maḥāsin al-Yūsufìyah, Staatsbibliothek zu Berlin, Wetzstein II 1893, folios 233v-235r.

${ }^{18}$ P.M. Holt, "The Sultan as Ideal Ruler: Ayyubid and Mamluk Prototypes”, in Suleyman the Magnificent and His Age: The Ottoman Empire in the Early Modern World, eds. I.M.

Kunt \& C. Woodhead (Oxford: Taylor \& Francis, 1995), 129.

${ }^{19}$ I am developing the implications of this circulation of Ibn Shaddād's work in Early Mamluk courtly contexts in much more detail in my PhD research.

${ }^{20}$ Vie de Saint Louis, $§ 2$. 
contemporary. ${ }^{21}$ However, this oldest known manuscript is a high-profile, richly decorated product and must have been intended for a courtly audience. Joinville explicitly states that he wrote the text after being requested to write about the saintly conduct of Louis IX by Joan of Navarre (d. 1305), wife of king Philip IV (r. 12851314), and mother of the later king Louis X (r. 1314-1316). The text was dedicated to the latter, and a number of exhortations are possibly addressed to him throughout the text. At the time, the young Louis was still a prince and is urged to follow Louis' example. $^{22}$

It is thus certain that Joinville was an old man as well by the year 1309, when he finished the biography. ${ }^{23}$ There has however been much scholarly discussion about whether or not the text was written as a whole at that time. The controversy mainly arises from the fact that, as noted above, more than half of the text deals with a mere six years of Louis IX's life during what is conventionally called the Seventh Crusade (1248-1254). In this part Joinville keeps to a chronological framework and writes extensively about his personal experiences, whereas the surrounding parts are more thematic and feature less of Joinville's presence. Furthermore, there are noticeable linguistic differences and changes in attitude between these parts. As a result, several historians have claimed that the Crusade narrative must have been written relatively soon after Joinville's return to France, and was later compiled with framing anecdotes

\footnotetext{
${ }^{21}$ It has been dated to about 1330-1340. The other two manuscripts are from the 15 th and the 16th century and are written in an updated French. Other copies are known to have existed but are lost. Monfrin, "Introduction", in Vie de Saint Louis, 92-94; Smith, Joinville and Villehardouin, xxxv and xlviii.

${ }^{22}$ Vie de Saint Louis, § 18-19 and 42.

${ }^{23}$ C. Smith, Crusading in the Age of Joinville (London \& New York: Routledge, 2006), 47.
} 
by Joinville to compose his biography. ${ }^{24}$ Notably, Jacques Monfrin, the editor of the authoritative text and modern French translation, disagrees and believes the text was written "d'un seul jet" between 1305 and $1309 .{ }^{25}$

A related point of much discussion revolves around the question of whether or not there was a unified theme or stylistic objective to Joinville's text. Many scholars have for example stressed its hagiographic nature, while others have claimed it should be read as a narrative mirror for princes. ${ }^{26}$ Caroline Smith has rightly noted that it is exactly the multiplicity of themes found in the text that make it such a rewarding read: rather than trying to define its main objective or to pin the elusive text down to a strict "genre", scholars should look at the various different types of frameworks used by Joinville in constructing his narrative. The way she wraps up this argument is also useful in evaluating Ibn Shaddād's text:

John of Joinville [was] a man familiar with literature of many sorts, both secular and spiritual, and $[. .$.$] he was ready to use what he knew of their methods to add$ interest to his own work. Although these techniques were certainly not applied consistently, and are usually visible only in isolated passages of the Vie de Saint

\footnotetext{
${ }^{24}$ For an overview of the debate, though very much in favour of the theory that the text was written at separate dates, see Smith, Crusading, 48-58.

${ }^{25}$ Monfrin, "Introduction", 79.

${ }^{26}$ For its hagiographic inclination, see among others: F. Laurent, "La vie de Saint Louis où le miroir des saints", in Le prince et son historien: La vie de Saint Louis de Joinville, eds. J. Durfournet \& L. Harf (Paris: Champion, 1997), 149-182. For the relation with advice literature: D. Boutet, "Le prince au miroir de la littérature narrative", in Le Prince au miroir de la literature politique de l'Antiquité aux Lumières, eds. Frédérique Lachaud an Lydwine Scordi (Mont-Saint-Agnan: Publications des universités de Rouen et du Havre, 2007), 159. Jacques Le Goff sees it as only a secondary aspect of the text, J. Le Goff, "Mon ami le saint roi: Joinville et Saint Louis", Annales. Histoire, Sciences Sociales 56, no. 2 (2001): 471.
} 
Louis, they demonstrate the fact that Joinville, like others who used such devices, had 'writerly ambition'. ${ }^{27}$

Taking the lead from this type of approach, this essay does not aim to resolve the discussion concerning when and how Joinville's text — or Ibn Shaddād's for that matter - was written, or which genre it belongs to, but rather focuses on the variety of techniques and narrative topoi applied by the authors to say something about the literary or, more generally speaking, discursive culture they had digested throughout their long lives and which they put to use in constructing their own narratives.

\section{The anecdotes}

The anecdote in Ibn Shaddād's text is first found in a list of anecdotes exemplifying Șalāh al-Dīn's virtues. Specifically, it is placed in a subsection dealing with "his patience and satisfaction with God's decree" (țaraf min șabri-hi wa-iḥtisābi-hi). ${ }^{28}$ These terms are in themselves already significant, as they had wide-ranging connotations in the Qur'ān, the hadīth, and beyond. ${ }^{29}$ The fact that Ibn Shaddād compiled such

${ }^{27}$ Smith, Crusading, 73. Smith refers to Ruth Morse's important study Truth and Convention in the Middle Ages (Cambridge: Cambridge University Press, 1991) for the quoted phrase. For a similar argument, see: D. Delogu, Theorizing the Ideal Sovereign: The Rise of the French Vernacular Royal Biography (Toronto, Toronto University Press: 2008), 23ff.

${ }^{28}$ Nawādir, 57. My translation.

${ }^{29}$ For example: Qur'ān, 2:155-157, 11:115, 12:90, 13:20-23, and 46:35. For its use throughout pre-modern Islamic literature: A.J. Wensinck, “Șabr”, Encyclopaedia of Islam, Second Edition, in: http://referenceworks.brillonline.com/entries/encyclopaedia-of-islam-2/sabr-

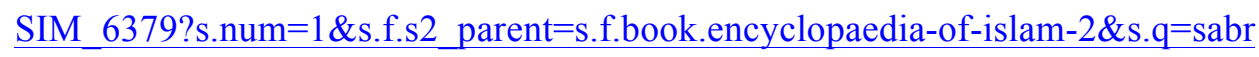


exemplifying anecdotes in a section on the sultan's virtuous behaviour is also quite suggestive for the importance he attached to this type of personal governance in his depiction of ideal rule.

I also observed him (la-qad ra'aytu-hu) when the news of the death of Taqī al-Dīn 'Umar, his nephew, came to him. [...] He summoned al-Malik al-'Ādil, 'Ālam alDīn Sulaymān b. Jandar, Sābiq al-Dīn b. al-Dāya and 'Izz al-Dīn b. al-Muqaddam and he ordered the men to be driven away from his tent, so that no-one remained closer than a bow-shot. Then he produced the letter, read it and wept so bitterly until he made us cry [too] (wa bakā bukā'an shadīdan hattā abkā-nā) without our knowing the cause. While the flood of tears exasperated him, he - may God have mercy on him — said, 'Taq̄i al-Dīn is dead.' His tears and those of the gathered company intensified, but then I came to myself and said (thumma 'adtu ilā nafsī), 'All ask pardon of God on account of this situation (istaghfarū l-Lāh min hädhihi lhạla). Consider where you [all] are, what you are about, and ignore all else.' And [the sultan] — may God have mercy on him — said, 'Yes, I ask pardon of God,' which he took to repeating (akhadha yukarrar-hā), finally saying, 'No-one must learn of this (lā yu 'lim bi-hädhā ahad). ' He requested some rose water and washed his eyes, then he had some food brought. His staff attended and no-one knew about it until the enemy retired to Jaffa and we withdrew to Latrun, where our heavy baggage was based. ${ }^{30}$

The anecdote makes a second appearance in different wording in the chronological part of the biography. The essence remains the same: Ibn Shaddād clearly notes his presence and assigns himself a crucial advisory role in pointing the sultan to the right path, stating that he "urged the sultan to think of God and [reminded him] that His decree and will must be fulfilled." 31

\footnotetext{
${ }^{30}$ Nawādir, 61; The Rare and Excellent History, 32. Translation emended by me. Italics mine.

${ }^{31}$ Nawädir, 296; The Rare and Excellent History, 190.
} 
Joinville's text also contains a section at the start of biography exemplifying the ruler's saintly virtues, although it is much less systematically organised than Ibn Shaddād's. The particular anecdote studied here is not found in this virtues section, however, but in the second part of the text that chronologically details Louis' activities in Egypt and the Holy Land during the Seventh Crusade:

\begin{abstract}
At Sidon news reached the king that his mother was dead. He displayed such profound grief (grant deul) that for two days no one could speak to him. After that he sent one of his chamber valets to fetch me. Once he saw that I had come into his presence in his chamber, where he was all alone, he reached out his arms and said to me, 'Ah! Seneschal, I have lost my mother!' 'My lord, that doesn't surprise me,' I said, 'since she had to die. But I am surprised that you, a man of good sense, have demonstrated such great sadness (je me merveille que vous, que estes un sage home, avez mené si grant deul). For you know that the wise man says (le Sage $d i t)^{32}$ that a man should not allow whatever distress he has in his heart to appear on his face, because he who does so makes his enemies happy and his friends upset.' He had many splendid services held overseas, and afterwards he sent a packhorse to France, loaded with letters to churches asking that they might pray for his mother. $^{33}$
\end{abstract}

The similarities between these two anecdotes are immediately clear: both authors present a sovereign who is unable to keep his emotions at bay in a moment of extreme grief and a companion - as we shall see, not coincidentally the author of the biography himself - who admonishes the ruler to behave according to an implicit norm

\footnotetext{
${ }^{32}$ Unspecified "sages" who utter wise truths occur a few times in Joinville's text, see also Vie de Saint Louis, §34, 38, 568. The term is also commonly used in describing actions or composure of noble persons, even for non-Christians (§ 348: "un sage home sarrazin"; $\S$ 475-7: Mongol sages).

${ }^{33}$ Vie de Saint Louis, § 603-604; Chronicles of the Crusades, 296.
} 
of emotional governance. Moreover, they both conclude with a mention of how the ruler dealt with the situation after having received wise counsel by the author-companion.

In fact, I am not the first to have noticed the similarity of these two accounts. Anne-Marie Eddé refers to the anecdote in Joinville's text when discussing the role of suffering in the overall portrayal of Șalāḥ al-Dīn in her authoritative modern biography of the sultan. ${ }^{34}$ Although she mentions the important narrative focus on "tears" in association with concepts of holiness, and thus implicitly notes that something similar might have been going on in the authorial process of composing these two narratives, she does not explore the shared frameworks of reference our authors relied on in constructing their texts and instead gives an overview of those moments in which Șalāḥ al-Dīn was depicted as giving in to emotions by his contemporaries.

\section{A discourse on the emotions}

Neither of these two anecdotes is unique in its portrayal of rulership and emotions. As Eddé already noted, they are not even the only anecdotes recorded by our authors in which the sovereign indulges in weeping or is confronted with grief. Only a few lines earlier in the same chapter on the ruler's virtues, Ibn Shaddād refers to another instance in which the sultan was given the news of the death of another close relative, this time of his pubescent son Ismā̄ $\mathbf{1}$ :

He read the letter but told nobody — and we did not know about it until we heard it from others - and showed nothing of that on his face, except that, when he read the letter, his eye shed a tear. ${ }^{35}$

\footnotetext{
${ }^{34}$ Eddé, Saladin, trans. Jane Marie Todd (Cambridge: Belknap Press, 2014), 359.

${ }^{35}$ Nawādir, 60; The Rare and Excellent History, 31. Translation emended by me.
} 
While it may seem surprising to find two anecdotes exemplifying such different behaviour of the sultan in the face of grief, it does make sense from a narrative point of view in this section to diversify the sultan's reactions at such moments. The crucial difference between the anecdotes in fact lies in Ibn Shaddād's role as moral guide. While in this shorter anecdote the sultan behaves appropriately and keeps his emotions to himself — aside from the small detail of one tear, apparently considered to be acceptable by Ibn Shaddād — in the one earlier quoted, Ibn Shaddād offers his wise consolation to remind the sultan of appropriate norms of behaviour.

For Ibn Shaddād, there was in fact a particularly potent precedent in Prophetic tradition for this type of emotional discourse, in the form of a well-known hadīth which describes the Prophet crying at the funeral of his infant son Ibrāhīm. Here too, a number of companions join in the crying, but Abū Bakr challenges the situation, asking the prophet why he is crying when he had earlier forbidden doing so at funerals. The Prophet then replies that moderate crying is allowed as long as one does not utter words that God would consider displeasing. ${ }^{36}$ A set of other traditions has the Prophet crying because of the deaths of Zayd - his once adoptive son - and other companions at the battle of Mu'ta, at which his crying is questioned by a number of different companions depending on the transmitted version. ${ }^{37}$ It is likely that the hadìth scholar Ibn Shaddād,

${ }^{36}$ A. Giladi, "Concepts of Childhood and Attitudes toward Children in Medieval Islam", Journal of the Economic and Social History of the Orient 32 (1989): 143-145. More general and detailed discussions in his monograph Children of Islam: Concepts of Childhood in Medieval Muslim Society (London, MacMillan: 1992), 69-100 I am grateful to Yasmin Amin and Muhammad Maslouh for drawing my attention to this tradition.

${ }^{37}$ D. Powers, Zayd (Philadelphia, University of Pennsylvania Press: 2014), 60-62. 
who explicitly quotes four traditions throughout the biography, ${ }^{38}$ also knew these accounts about the Prophet's behaviour in the face of sorrow. He might even have been aware of what Avner Giladi has called consolation treatises, a small genre of texts intended for bereaved parents, in which the tradition about Ibrāhīm's death is routinely quoted. Two keywords in these treatises, șabr and ihtisāb, are also the two qualities to which Ibn Shaddād devotes the particular subsection of his virtues chapter.

Joinville's anecdote is also not an isolated instance. His biography in fact includes many accounts of persons - including Louis and Joinville himself - crying in various situations. As much research on textual renderings of medieval emotions has shown, tactical and performative display of emotion was in many ways part and parcel of the noble habitus of Joinville and his peers. ${ }^{39}$ For example, Joinville recounts how he wanted the king to take care of the upkeep of several knights from Champagne who had been released from captivity while the king was in Acre. After being berated by one of the king's counsellors for bothering the king with this request, Joinville was able to secure the king's willingness by crying. ${ }^{40}$ Yet, we also see in other accounts that there were normative limits to crying, especially for the king. In at least one similar anecdote the dynamic between ruler and advisor is played out in the context of grief when Louis is informed about the death of his brother, the count of Artois, during the battle of

${ }^{38}$ The Rare and Excellent History, 18, 35, 77, 89.

${ }^{39}$ Gerd Althoff, Die Macht der Rituale (Darmstadt: Primus, 2003). See also more generally, Rosenwein, "Thinking Historically about Medieval Emotions": 830-833.

40 "Je commensai moult forment a plorer; et le roy me dit que je me teusse, et il leur donroit quant que je li avoie demandé." Vie de Saint Louis: § 468. An earlier anecdote also involves several people crying for the plight of captured knights, which apparently urged the king to make available funds to release them: $\S 427$. In $\S 416$, Joinville's prayer accompanied by crying (“je plorai et rendi graces a Dieu”) results in him and his retinue being spared from disease. 
Manșūra (1250). Here too, the king starts crying inconsolably. While Joinville remains in the background - he has in the directly preceding paragraph noted that he went to the king's "arrière-guarde" — Henri de Ronnay, "prévôt de l'Hôpital” exhorts the king to restrain his emotions by taking comfort in the glory arising from his impressive military achievements in Egypt up to that point. ${ }^{41}$ I will return to the significance of this last episode below. Similar anecdotes can also be found in other European narratives of kingship. ${ }^{42}$

We may thus conceive of our authors tapping into a literary discourse on the emotions that was quite widespread in the period, with direct parallels at least as far back as early hadīth. One fruitful way of examining these parallel discourses beyond what I have done so far, is by looking at the tradition of advice literature. This includes those texts that are often referred to as "mirrors for princes", as well as the nașinhat almulūk of the Arabic tradition, but the more general term "advice literature" also allows us to include several disparate texts that aimed to contribute to the edification of a (future) ruler, such as the regnal biographies studied here. As is well known this type of

${ }^{41}$ Vie de Saint Louis: § 243-244. Michel Zink has argued that Joinville's evaluation of Louis' tears in this particular anecdote alludes to Saint Bernard of Clairvaux's deploration of his brother Gerard's death in a sermon on the "Song of Songs". M. Zink, "Joinville ne pleure pas mais il rêve", Poétique: Revue de théorie et d'analyse littéraires, 33 (1978): 33-36. On this particularly famous example of medieval emotional discourse, see also: M.B. Pranger, “Augustine and Bernard of Clairvaux on Tears and the Self", Fragmenta, 3 (2009): 31-38.

${ }^{42}$ See for one example about Louis IX's contemporary king James I of Aragon (d. 1276), who rebukes persons in his retinue for crying during the burial of two prominent noblemen who had died while fighting in Mallorca: The Book of Deeds of James I of Aragon: A Translation of the Medieval Catalan Llibre dels Fets, ed. Damian J. Smith and Helena Buffery (Farnham: Ashgate, 2010), 92. See also A. Liuzzo Scorpo, "Emotional Memory and Medieval Autobiography: King James I of Aragon (r. 1213-76)'s Llibre dels fets", Journal of Medieval Iberian Studies, 10, vol. 1 (2018): 9-11 and passim. 
writing had a parallel popularity on both sides of the Mediterranean. ${ }^{43}$ Because both our authors implicitly (Ibn Shaddād) or explicitly (Joinville) framed their depiction of ideal rule as narrative exempla, comparing our biographies to a number of key texts from the broader advice tradition creates a meaningful way to explore their narrative use of emotional discourse.

To undertake this exploration, I have focussed on a small but representative number of texts. Rather than fully explore the position of these texts in twelfth and thirteenth century thought, I will evaluate them as iterations of a discursive matrix that had wide currency in these societies and which was received and actively reproduced by our authors. For that reason I will not be giving an overview of the traditions of advice literature as circulating in the Islamic world and Western Europe, but rather choose advice texts that were either more or less contemporary with our authors or had acquired an influential position by their lifetime.

The first text studied is perhaps the most famous medieval example of the royal advice tradition: the Sirr al-Asrār or Secretum Secretorum, in which an author purporting to be Aristotle gives advice to Alexander the Great - a pairing that would grow into a topos of much other didactic literature. ${ }^{44}$ This originally Arabic work contains much content presumably derived from Hellenistic or Roman pseudo-

${ }^{43}$ L. Darling, "Mirrors for Princes in Europe and the Middle East: A Case of Historiographical Incommensurability" in: East Meets West in the Middle Ages and Early Modern Times: Transcultural Experiences in the Premodern World, ed. A. Classen (Berlin \& Boston: De Gruyter, 2013), 223-242.

${ }^{44}$ L. Marlow, “Advice and Advice Literature”, Encyclopaedia of Islam, Third Edition, in: http://referenceworks.brillonline.com/entries/encyclopaedia-of-islam-3/advice-and-adviceliterature-

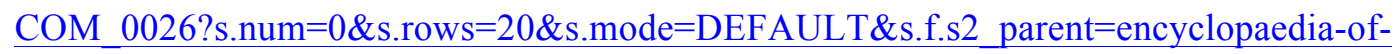
islam-3\&s.start $=0 \&$ s.q $=$ advice 
Aristotelian epistles that were translated into Arabic at some point during the Umayyad period. The work only took its full eclectic form only around 1100. At some point in the early thirteenth century it was translated into Latin in Tripoli and quickly spread throughout Europe, both in Latin and in various vernacular translations and adaptations. $^{45}$ All of these versions, known under a wide variety of titles, were extremely popular. ${ }^{46}$ I have here relied on Ahmad Badawī’s edition of the most common Arabic version, which is followed closely by Roger Bacon's Latin version. ${ }^{47}$ Because of its wide availability in the literary contexts in which both Ibn Shaddād and Joinville worked, I am assuming that its ideas would have been at least indirectly familiar to our authors.

The two other texts I have consulted circulated or were intended to circulate in the direct social environments of our authors. The first of these is al-Nahj al-maslük fi siyāsat al-mulūk, written by the scholar 'Abd al-Raḥmān b. Naṣr al-Shayzarī (d. 1193), who dedicated it to Șalāh al-Dīn. Although it is not known whether the sultan actually received and read the text, we can at least assume that it expressed ideas that would

${ }^{45}$ For an extensive discussion of the identity of the text's possible translators: S.J. Williams, The Secret of Secrets: The Scholarly Career of a pseudo-Aristotelian Text in the Latin Middle Ages (Ann Arbor: University of Michigan Press, 2003), 65-91.

${ }^{46}$ The European text is often named as the Medieval bestseller with roughly 600 manuscripts surviving to this day. Of the Arabic versions about fifty manuscripts were known to Mahmoud Manzaloui, again a very high number. M. Manzaloui, "The PseudoAristotelian 'Kitāb Sirr al-asrār': Facts and Problems”, Oriens 23/24 (1974): 147-257.

${ }^{47}$ Aḥmad Badawī in Al-ușūl al-Yūnāniyya li-l-nazariyyāt al-siyāsiyya fì l-islām, (Cairo, Dār alkutub al-Mișriyya: 1954), 67-171. A translation of the text into English can be found in: R. Bacon, Secretum Secretorum cum Glossis et Notulis, ed. R. Steele, trans. A.S. Fulton (Oxon: E Typographeo Clarendoniano, 1920), 176-266. 
have been favourably received at his court. ${ }^{48}$ The last text I have looked at is the Old French translation of Egidius Romanus' (Giles of Rome, d. 1316) De Regimine Principum, entitled Li livres du government des rois. Giles was an intellectual giant of the period who had studied under Thomas Aquinas, and applied much of the knowledge he acquired under Aquinas in this important work. Finished around 1280, it quickly became one of the most widespread European mirrors for princes after the Secretum Secretorum, with about 350 known surviving manuscripts. ${ }^{49}$ The earliest manuscript of the Old French translation entitled Li livres du gouvernment des rois is dated to 1282 , and will be the version of the text used here. It is known that Louis X's widow Clemencia of Hungary owned a copy of this version, bringing it into very similar courtly circles as those for whom Joinville's text was intended. ${ }^{50}$

Most of the texts looked at here do not address emotion as a conceptual category in itself. Rather, emotions such as crying, laughing, happiness, etc. are grouped in the container of "passions" or "desires" (Arabic: shahwa - shahawāt; hawā - ahwā')

${ }^{48}$ S. Leder, "Sultanic Rule in the Mirror of Medieval Political Literature", in: N. Yavari \& R. Forster (eds.): Global Medieval: Mirrors for princes revisited, (Cambridge: Harvard University Press: 2015), 101-103. The text was rediscovered in the late Ottoman period. L.T. Darling, A History of Social Justice and Political Power in the Middle East: The Circle of Justice from Mesopotamia to Globalization, (Oxon-New York: Routledge, 2013), 152.

${ }^{49}$ C.F. Briggs, Giles of Rome's De Regimine Principum: Reading and Writing Politics at Court and University, c.1275-c.1525 (Cambridge: Cambridge University Press, 2008), 3. See also: N.-L. Perret, Les traductions françaises du De regimine principum de Gilles de Rome: Parcours matériel, culturel et intellectuel d'un discours sur l'éducation (Leiden: Brill, 2011)

${ }^{50}$ Briggs, Giles of Rome, 16. 
throughout most advice literature. ${ }^{51}$ Consider for example this excerpt from Sirr alasrār where the author talks about the management of anger, which depends foremost on the management of passion:

If [the ruler] happens to fall into anger (idhä ghadiba) he should take care not to act on the impulse of the moment without reflection. When passion (shahwa) stirs in him he should [respond to it] with the power of reason (radda-hä bi- 'aqli-hi), and rule his own soul (malaka nafsa-hu). And if his passion is righteous, he should act upon it without showing violence or contempt. ${ }^{52}$

Among the many assorted bits of advice found in this text, there are similar injunctions "against excess" and for "moderation and temperance." $" 53$ In concluding an anecdote about Hippocrates overcoming his desires by reason, it is stated that philosophers need to "subjugate [their] desires to [their] reason", for "philosophy is merely mastering desires" (al-falsafa innamā hiya milk al-shahawāt). ${ }^{54}$

Similar ideas are found in al-Shayzarī’s al-Nahj al-maslük. When discussing at length the importance of $a d a b$ or proper edification for a just ruler (malik 'adil), the author writes about two fundaments: adequate knowledge of various things ( $\mathrm{ilm}$ ) and "the soul's renunciation of desire" (nahy al-nafs 'an al-hawā). The idea here is that a king should first control his own soul and his emotions before he can hope to control his

\footnotetext{
${ }^{51}$ N. Yavari, "Mirrors for Princes or a Hall of Mirrors: Niẓām al-Mulk's Siyar al-mulūk Reconsidered", al-Masaq 20, vol. 1 (2008): 52

52 Secretum Secretorum, 185. Translation slightly emanded by me based on Badawī, 77-8.

${ }^{53}$ Secretum Secretorum, 194.

${ }^{54}$ Secretum Secretorum, 219; Badawī, 187.
} 
subjects. $^{55}$ The didactic function of $a d a b$ is thus twofold: it requires acquiring knowledge from outside of oneself, but it is also an internal process of ridding oneself of overtly passionate tendencies. Al-Shayzarī's discourse echoes a few key elements from the Sirr al-asrār in this section, such as the association of controlling the five senses with controlling the soul and its passions. Similar ideas can be found throughout much medieval Islamic literature that circulated during the twelfth century. Abū Hāmid al-Ghazālī's (d. 1111) widely read masterpiece Ihyā 'ulūm al-dīn for example extensively discusses the importance of patience ( $(\mathrm{s} a \mathrm{br})$ in one's comportment. Here, alGhazāli expounds the idea that one should accept grief and have "satisfaction with God's decree." 56

Thomas Zahora has argued that throughout the thirteenth and fourteenth century discourses on passions, desires, and emotions changed considerably in European advice literature. Because of the influence of newly translated works by Aristotle and the commentaries by Aristotelian philosophers, especially those of Thomas Aquinas, this discourse gradually broke loose from an earlier framework in which emotions had been seen primarily as virtues and passions. ${ }^{57}$ Appropriate emotional governance in itself subsequently became a crucial aspect of discourse on ideal royal behaviour. One of the authors Zahora based his argument on is Giles of Rome, the author of Li livres $d u$ gouvernment des rois, whom he saw as a transitional figure in this regard. The work is divided into three books: "the government of self", "the government of the family", and

${ }^{55}$ Al-Shayzarī, Kitāb al-nahj al-maslūk fì siyāsat al-mulūk, ed. Muḥammad Ḥassan Isma ${ }^{\mathrm{c}} 1 \mathrm{l}$ \& Aḥmad Farīd al-Muzaydī (Beirut Dār al-kutub al- cilmiyya: 2003): 83.

${ }^{56}$ Abū Ḥāmid al-Ghazālī, Ihyya ưūum al-dīn, (Beirut: Dār Ibn Ḥazm, 2005), 1399-1487. Summarised in M.A. Sherif, Ghazali's Theory of Virtue (Albany: State University of New York Press, 1975), 128-9.

${ }^{57}$ T. Zahora, "Since Feelings is First: Teaching Royal Ethics through Managing the Emotions in the Late Middle Ages", in: Parergon, 31, vol. 1 (2014): 48. 
"civil government", which agrees with al-Shayzarī’s contention that a successful sovereign needs to control himself first before he can control more complex social constellations, starting with his own family and ultimately ending in the government of his realm. The first book on the self is divided into four parts: "on the highest good", "of virtue", "of the emotions", and "of habits." 58 The fact that Giles deals with virtues and emotions in separate subsections lends support to Zahora's evaluation of a changing discourse on the emotions. On the other hand, Giles' somewhat ambiguous position is clear when he talks about "proper behaviour for kings and princes when confronted with sorrow and joy" (“comment les rois et les princes se doivent avoir avenaument en delit et en richeces") where a certain ambiguousness in terms remains present. After stating that "one should not show great sadness", ${ }^{9}$ he goes on to mention three methods for countering excessive grief: behaving virtuously ("li hons ait bones vertuz"), having the comfort of friends ("le confort des amis"), and knowing justice (“conoistre justice"). Virtue thus remained of crucial importance in the evaluation of emotions for Giles. He concludes in a way that is reminiscent of Joinville's "sage":

These three things we have mentioned remove sadness principally and as such Kings must temper grief and their sadness, just like they have to surmount others in doing deeds of virtue. ${ }^{60}$

${ }^{58}$ S.P. Molenaer (ed.), Li livres du gouvernment des rois: A XIIIth Century French Version of Egidio Colonna's Treatise De Regimine Principum, (London: MacMillan, 1899): xxxvxlii.

59 “Nos dirrons que nule tristece n'est bone, ne ne fet a loër, ne nus ne doit prendre tristece." $L i$ livres du gouvernement des rois: 114. My translation.

60 "Mes ces .iii. choses que nos avons dit ostent la tristece principaument, et de tant doivent les rois plus a temprer la doleur et lour tristece, cum plus doivent les autres sormontier en fere les euvres des vertuz." Li livres du gouvernement des rois: 115. My translation. 


\section{The author-companion as vector of emotional governance}

It is clear that a shared idea is prevalent both in the didactic works and in our authors' regnal biographies, namely that displaying excessive grief - or more generally, passion - does not befit a ruler, for a ruler must show appropriate governance of his emotions in his position as role model for his subjects. What makes our anecdotes unique, however, and what makes them rewarding as insights into the narrative construction of these texts, is not that our authors depict a ruler's excessive grief or his adequate tempering of that grief, but that they depict the sovereign's interaction with his close companion in that context of grief. Both authors stress their personal relation to the sultan continuously throughout their texts.

Ibn Shaddād does so already in his introduction with a tahmīd (praise section) that builds on common themes of the admonishing and exemplary roles of history and biography and then commences his main introduction with the words lammā ra'aytu ("when I saw", or even "since I have seen"), thus highlighting the personal and necessary nature of the account to follow. ${ }^{61}$ This establishes a clear association between the introductory discourse on exemplary history and the one who is communicating that history, which ultimately validates his own text because it is largely and explicitly based on personal recollection. Joinville too, continuously stresses his presence and uses it as a tool to argue for the superiority of his text. For example, he explicitly states in his introduction that the book's account about Louis' death was based on that of count Pierre d'Alençon, "who had much affection for me". By explicitly referring to a reliable outside source for a part in which the author was not himself present, Joinville underlines the importance of his personal attendance and intimate recollection of many

\footnotetext{
${ }^{61}$ Both anecdotes he gives in the virtues subsection also start out by explicitly noting Ibn Shaddād's personal observation of the happenings. Al-Nawādir, 61-62.
} 
accounts in the rest of the book. ${ }^{62}$ This is taken even further in the book's conclusion, where he states that it can only be considered entirely truthful in those parts where it is based on Joinville's own recollection:

I hereby inform everyone that I have set down here a great number of the deeds of our saintly king that I saw and heard myself (que je ai veu et oÿ), as well as a good number of his deeds that I found in a book in the French language [a version of the Grandes Chroniques de France] and which I have had written down in this work. I am bringing these things to your attention so that those who hear this book might firmly believe what it says about those things I did truly see and hear myself (que j'ai vraiment veus et ö̈es). I cannot state whether the other things written down here are true since I neither saw nor heard them. ${ }^{63}$

Aside from the value of personal presence as a powerful truth claim, however, both Ibn Shaddād and Joinville also use their presence for narrative ends. In the case of Joinville, this has been amply studied. Michèle Perret has for example suggested that much of the narrative presentation of the relationship between the ruler and his companion in Joinville's work can be seen as a variation on the topos of "the brave and the wise" ("le preux et le sage"), taken from the epics that were popular in noble circles of late medieval France. ${ }^{64}$ On a more general level, Daisy Delogu has argued that Joinville's pervasive presence throughout the Vie de Saint Louis is meant to work as a mirror for the reader to identify with the author's perception of the ruler. By placing himself in the position of admiring companion who observes and learns from Louis' saintly royal behaviour, Joinville is "essential to the reader's understanding of Saint Louis, for the seneschal allows us to measure and appreciate the full extent of the king's

\footnotetext{
${ }^{62}$ Vie de Saint Louis, $\$ 4$.

${ }^{63}$ Vie de Saint-Louis, §768; Joinville and Villehardouin, 335-336. My italics.

${ }^{64}$ M. Perret, “...A la fin de sa vie ne fuz-je mie": 33.
} 
saintly conduct." ${ }^{65}$ As a result, this self-portrayal "creates a space for the public within the confines of Joinville's text, allowing the reader to join the author in his admiration and imitation of Saint Louis."

In such a context, it makes narrative sense to diversify the relation between ruler and companion, not only as one of admiration but also as one of mutual support, in which the companion appears as critical of the ruler's actions, or as crucial for the ways in which political decisions were made. This is again true as much for Ibn Shaddād as it is for Joinville. In general, both authors usually praise the ruler for his virtuous behaviour, but there are several instances in which the sovereign's decisions are criticised. When Ibn Shaddād talks of the later events of Șalāh al-Dīn's life, the ruler often seems to lose his serenity, acting rashly and overtly influenced by his passions, such as when he has several small groups of Frankish prisoners executed during the Third Crusade. Here Ibn Shaddād tries to be the voice of reason and morally criticizes these actions, which emanated from a general sense of despair in the Muslim camp. ${ }^{67}$ Elsewhere, Ibn Shaddād calms and consoles the sultan when bad news of overtaken reinforcements arrives, ${ }^{68}$ or is the only one to whom the sultan discloses his true feelings concerning a possible peace treaty with the Franks. ${ }^{69}$ Joinville too, sometimes

${ }^{65}$ D. Delogu, Theorizing the Ideal Sovereign, 40.

${ }^{66}$ Ibidem, 42.

${ }^{67}$ The Rare and Excellent History, 168-170. Anne-Marie Eddé argues that these executions should be seen as reprisals for the Franks' massacring of Muslim prisoners after recapturing Acre, and were thus considered to be "legitimate" (Saladin, 195). I believe Ibn Shaddād's attitude here actually deligitimises these actions by painting them as not befitting a serene ruler.

${ }^{68}$ The Rare and Excellent History, 208.

${ }^{69}$ The Rare and Excellent History, 195. 
openly criticises the king's decisions, especially those of a military nature. ${ }^{70}$ A particularly clear example is found when Joinville evaluates Louis' decision to take the cross again to attack Tunis in what is conventionally called the Eighth Crusade. Here our author writes that those who advised the king to do so committed "a great sin", considering the peaceful state of France, which worsened immediately after the king's departure on the one hand, and Louis' bodily weakness on the other hand. ${ }^{71}$ Elsewhere, criticism is more implicit, such as in Joinville's account of the ill-advised decision to march south to Cairo ("Babiloine") after the conquest of Damietta, instead of securing Alexandria with its "bon port" first. ${ }^{72}$ Here, as elsewhere during the first part of the disastrous Egyptian campaign, Louis is shown as strongly relying on the advice of his brother Robert, the count of Artois, while often disregarding the advice of his barons. As noted above, when Robert died somewhat later during the Battle of al-Manșūra, Joinville describes how Louis cried excessively and was criticised for doing so by one of his nobles. The impression that Joinville, while certainly already very present in the narrative depicts himself increasingly as a close counsellor of the king himself from this point onwards, may mean that Joinville gradually took over Robert's place as brotherly counsellor, at least within the text's narrative logic.

All these accounts serve to continuously stress the crucial importance of the ruler's reliance on advisors, which establishes a strong parallel to the idea that a ruler must surround himself with able and wise advisors found throughout many, if not all

\footnotetext{
${ }^{70}$ J.M. Elukin, "Warrior or Saint? Joinville, Louis IX's Character and the Challenge of the Crusade”, in: K.L. Jansen, G. Geltner \& A.E. Lester (eds.), Center and Periphery: Studies on Power in the Medieval World in Honor of William Chester Jordan (Leiden: Brill, 2013), 183-194.

${ }^{71}$ Vie de Saint Louis, § 736-737.

${ }^{72}$ Vie de saint Louis, § 183.
} 
advice texts, from Sirr al-asrār to Niccolò Machiavelli’s Il Principe. ${ }^{73}$ The specific relationship found in the two biographies of Ibn Shaddād and Joinville can be seen as an internalised and narratively illustrated form of this idea. Aristotle is here not addressing Alexander, so to speak, but writes a regnal biography of Alexander in which his own role as advisor is illustrated as having been politically but also morally crucial. Our authors present themselves as moral counterbalance to the ruler's impulsive or overtly passionate behaviour, as the voice of reason that tempers the soul's passions, as wise advisor able to steer the king's decisions in correct directions. While praising the virtues of the rulers they once served, both authors also continuously stress the importance of his advisors, not in the least themselves, for attaining the full potential of those virtues, indicating that a king can only be as good as his advisors allow him to be. In both cases, the ideal ruler's ideal advisor is easily identified as the author himself. Our authors exhort contemporaneous, and perhaps even future rulers to behave according to the governance exemplified by the deceased and lauded ruler depicted, but also exemplify the ruler's ideal courtly circles, in the form of their own personalities.

\section{Conclusion}

Although Ibn Shaddād and Joinville wrote their texts in completely different contexts, the influence of a prevalent political discourse is felt in both biographies. Ideas about the necessity of emotional restraint in the ruler's comportment and the centrality of advisors in his political project clearly resonated across geographic and chronological boundaries and came together in surprisingly similar ways in the independent biographical projects of our authors. While it is impossible to define what exactly our

\footnotetext{
${ }^{73}$ Secretum Secretorum, 235; Badawī, 136. N. Machiavelli, The Prince, tr. G. Bull (London:
} Penguin Books, 2003), 74-75. 
authors had in mind when composing these specific anecdotes, this essay has demonstrated how a number of discourses on political advice and emotion circulated and were engaged with in important works in the Islamic world and Western Europe between the late twelfth and early fourteenth centuries, not in the least by the authors of these two regnal biographies. Furthermore, this essay has shown the possibilities of researching cross-cultural narrative configurations of ideas also expressed in texts of a more theoretical inclination, highlighting the continuity of literary expression across genre boundaries, and indeed in many ways also across geographical boundaries. Similarly ideas about rulership and the centrality of advice to his political project may be found in many other literary contexts.

How may we conceive of Ibn Shaddād and Joinville writing these accounts? One is tempted to imagine them as old men nostalgically looking back on their long lives, perhaps comparing the accounts from those times favourably to contemporary times. Specifically, they would reminisce about the eventful years they spent in the company of rulers who had by then been canonised as heroes, as a saint even in the case of Louis IX. But neither author wrote a merely nostalgic recollection: looking back at those times, they composed exemplifying narratives by which they actively participated in contemporary political discourse on ideal rulership. 